\title{
THE INFLUENCE OF MEDICATION DAYS' SUPPLY ON ADHERENCE AND COST OF HYPERTENSIVE PATIENTS AT PRIMARY HEALTH CARE CENTRE
}

\author{
Catur Dian Setiawan, Nurul Wathaniah, Atikah Rahmaniah, Primanda Ayu Maharani, \\ Azzahroh Sifa' Lailiyah Mahmudah, Mufarrihah*, Gusti Noorrizka Veronika Achmad
}

\begin{abstract}
Faculty of Pharmacy Universitas Airlangga Jl. Dharmawangsa No.4-6, Airlangga, Gubeng, Kota SBY, Jawa Timur 60286
\end{abstract}

Submitted: 07-09-2017

Revised: $05-10-2017$

Accepted: 24-11-2017

*Corresponding author Mufarrihah

Email:

mufarrihah@ff.unair.ac.id

\begin{abstract}
Primary Health Care Centre is known of having policy discrepancy with the supply of medicines. This can influence the adherence and costs incurred by patients. The study aimed to identify the influence for hypertensive patients at Primary Health Care Centre in Surabaya. This study was designed cross sectional and data collection was conducted by using ARMS questionnaires for the patient's adherence and interview for the cost of the treatment. The cost was calculated based on the frequency of real visits and monthly patient expenditures. Direct medical cost, direct non medical cost, and indirect cost were included based on patients' perspective. Direct observations were performed to calculate the days of drug supplies. A total of 406 patients from 50 Health Care Centre were included in the study. Days of drug supplies ranged from 3 to 30 days; total ARMS scores ranged from 12 to 33; and the total cost obtained ranged from IDR 34,965 to IDR 239,528 . The Spearman's correlation test sought to obtain the significant influence of medication days' supply on adherence with $p$ value 0.0001 and $r=-0.347$. While medication days' supply didn't show any significant influence on the cost. It will be significant if the patient met the visit schedule, that was $p$ value 0.0001 and $r=-0.247$. It is recommended to prolong antihypertensive days' supply in order to improve patients' adherence, as well as to reduce cost expensed by patients.
\end{abstract}

Keywords: adherence, cost, hypertension, medication days' supply, Primary Health Care Centre

\section{INTRODUCTION}

Hypertension is one of the leading causes of premature death worldwide. It is often referred as a silent killer because it does not show symptoms and many people do not realize it (WHO, 2011). In 2013, the prevalence of hypertension in Indonesia at age $\geq 18$ years was $25.8 \%$ (Kemenkes RI, 2013). In Surabaya, there were 818,331 patients who visited primary heath care centre in 2015, and as many as $16.78 \%$ suffered from hypertension (Dinkes Surabaya, 2015).

Hypertension can be controlled by providing appropriate therapy both nonpharmacological therapy and pharmacological therapy (Depkes, 2006). Pharmacological therapy using antihypertensives is a long-term therapy. Long-term therapy can lead to nonadherence. Non-adherence in the treatment will have a negative impact, such as treatment failure, incidents of complications that aggravate health conditions, increased incidents of illness in hospitals, and rising health costs (Voorham, et al., 2003). Based on research conducted on 7,981 patients with hypertension under age of 65 , it is indicated that low adherence rates may increase medical costs, drug costs and the risk for hospitalization so that the total costs incurred become larger (Sokol, et al., 2005).

Primary health care centre as first-rate health facilities in the treatment of hypertension is known to have different policies in providing the amount of drugs to patients. The number of days of drug administration for hypertensive patients at some primary health care centres in Surabaya ranges from 5 to 10 days (Aldila, 2015; Ananda, 2015; Riska, 2015). The short 
number of medication days' supply cause the patients to have to visit the primary health care centre several times a month to get the medicine. This will affect the adherence and costs incurred patients.

Research on adherence of hypertensive patients has been widely conducted (Hussar, 2005; Aldila, 2015; Ananda, 2015; Riska, 2015) as well as research on adherence associated with the cost of treating hypertension (Sokol et al., 2005). Meanwhile, research on the number of days of drug administration associated with adherence and cost had never been done in Indonesia. There was a research in America that associated the number of days of drugs administration with adherence and cost (Taitel et al., 2012). However, in that research, the medication days' supply is given in a long enough time that is between 30-90 days. Meanwhile in Indonesia the number of days of drug administration is between 5-10 days. Therefore, it is necessary to conduct research on the influence of medication days' supply on adherence and cost from the perspective of the patient so that later can be used as input to primary health care centre in order to give more effective and efficient service to society.

\section{MATERIAL AND METHODS}

This research was a survey that was designed cross sectional. Data was collected from February to May 2017. Compliance data were collected from ARMS questionnaire, cost data was obtained from interview result, and data on the number of days of drug administration was obtained from observation to respondents by counting the amount of drug received by the respondent.

Sample in this research was a number of hypertension patients who get service at primary health care centre in Surabaya. The inclusion criteria of the sample included 1) patients who had been diagnosed with hypertension and took antihypertensive drugs for at least 1 month, 2) hypertensive patients who did outpatient treatment at primary health care in Surabaya, 3) hypertensive patients with age $\geq 18$ years, 4) patients of hypertension receiving services from primary health care centre during the month of research, 5) patient who were able to communicate well, and 6) willing to be a research respondent. The exclusion criteria of this study sample were patients who were not a permanent patient of the primary health care centre. Sampling was conducted using non random sampling method with accidental sampling technique.

Adherence was measured by calculating the total ARM score, where the smaller total ARM score indicates that patient adherence is higher. The cost was measured based on patients perspective. The cost incurred by the patient included direct medical cost, direct nonmedical cost and indirect cost. Cost data was obtained by interview patients. Direct medical cost included cost incurred by patients to purchase antihypertensive drugs at pharmacies, laboratory examination costs, and doctor consultation fees outside primary health care centre over the past month. Direct non medical cost included transportation cost and administrative cost. Transportation cost was the cost of public transport issued by the patient or the cost of vehicle fuel per kilometer multiplied by the distance of the patient's house to the primary health care centre, pharmacy, or doctor including the parking fee in the last month. Administrative cost was cost incurred by patients who do not have Surabaya's ID card or family card to get services in health centres. Indirect cost was cost caused by the loss of patient productivity due to not working for the control of the illness and getting medication at the health centre during the last month based on the patient's information during the interview. The effect of medication days' supply on adherence and cost was analyzed by Spearman correlation test.

\section{RESULT AND DISCUSSION}

From February to May 2017, 406 respondents who met the inclusion criteria were found in 50 primary health care centres in Surabaya as presented in Demographic data of respondents (Table I). Based on the data (Table I), seen that $71.67 \%$ of respondents were women. This result was in accordance with the health profile data of Surabaya city where the number of female patients were higher than that of men (Dinkes Surabaya, 2015). 
Table I. Demographic data

\begin{tabular}{|c|c|c|}
\hline & Data & n (\%) \\
\hline \multirow[t]{2}{*}{ Sex } & Women & $291(71.67)$ \\
\hline & Men & $115(28.33)$ \\
\hline \multirow{7}{*}{ Age (years) } & $<35$ & $1(0.25)$ \\
\hline & $35-39$ & $5(1.23)$ \\
\hline & $40-44$ & $16(3.94)$ \\
\hline & $45-49$ & $37(9.11)$ \\
\hline & $50-54$ & $53(13.05)$ \\
\hline & $55-59$ & $56(13.79)$ \\
\hline & $\geq 60$ & $238(58.62)$ \\
\hline Insurance & BPJS & $380(93.59)$ \\
\hline \multirow[t]{2}{*}{ membership } & General & $25(6.16)$ \\
\hline & Other insurance & $1(0.25)$ \\
\hline \multirow[t]{16}{*}{ Work } & Retired / Not working & \\
\hline & Self-employed / trader & $130(32.02)$ \\
\hline & Civil servants & $47(11.58)$ \\
\hline & Private employees & $3(0.73)$ \\
\hline & Teacher & $11(2.71)$ \\
\hline & Technician & $3(0.73)$ \\
\hline & Guardian of the & $4(0.99)$ \\
\hline & foundation & $1(0.25)$ \\
\hline & Shopkeeper & $1(0.25)$ \\
\hline & Tailor & $1(0.25)$ \\
\hline & security & $2(0.49)$ \\
\hline & Housemaid & $6(1.47)$ \\
\hline & Church officials & $1(0.25)$ \\
\hline & Construction laborers & $2(0.49)$ \\
\hline & Driver & $1(0.25)$ \\
\hline & Housewife (IRT) & $193(47.54)$ \\
\hline
\end{tabular}

The prevalence of hypertension in women is greater than that of men due to increased blood pressure associated with estrogen hormone changes, overproduction of pituitary hormones, weight gain, oral contraceptive use, and unexplained non-hormonal influences (Chobanian et al., 2003).

One of the factors that increase blood pressure is age, and it generally occurs in old age (Chobanian et al., 2003; Rajpura and Nayak, 2014). The data showed that $58.62 \%$ of respondents were elderly patients (patients aged $>60$ years). It was similar to a study in Nepal that showed the highest prevalence was 59.3\% among participants above 60 years of age (Khanal et al., 2017).

The risk of hypertension can occur at the age above 18 years. The risk of hypertension in people with normal blood pressure will increase around the age of 55 years (Saseen and MacLaughlin, 2008). The high risk of hypertension is in line with age due to structural changes in the large blood vessels, so the lumen becomes narrower and the blood vessel wall becomes stiff causing increased blood pressure (Kaplan, 2002).

Data (Table I) showed that $93.60 \%$ of respondents have health insurance BPJS. This was in accordance with the vision of BPJS that no later than 2019 the entire population of Indonesia has become a BPJS participant (BPJS Kesehatan, 2013). There was a study that mention that most elderly use health insurance as a source of health funds (Yenny and Herwana, 2006). The existence of this health insurance can reduce the possibility of patients not seeking treatment and not redeeming the drug because of expensive prices. 
Table II. Average total ARMS score

\begin{tabular}{ccc}
\hline Medication days' supply & n & Average total ARMS score \\
\hline 3 days & 7 & $17.58 \pm 4.72$ \\
4 days & 2 & $16.00 \pm 5.29$ \\
5 days & 66 & $18.99 \pm 4.91$ \\
6 days & 31 & $17.37 \pm 5.60$ \\
7 days & 42 & $17.37 \pm 4.51$ \\
8 days & 4 & $15.50 \pm 4.39$ \\
10 days & 195 & $20.44 \pm 3.21$ \\
14 days & 16 & $14.69 \pm 4.06$ \\
15 days & 4 & $13.30 \pm 5.41$ \\
30 days & 39 & $13.64 \pm 2.65$ \\
\hline
\end{tabular}

Employment data of respondents showed that as many as $47.54 \%$ of respondents were housewives (Table I). Most of respondents were housewives due to the prevalence of hypertension is greater in women than men (Hussain et al., 2016). In addition, the time required to seek treatment at primary health care centre is long enough, according to some patients approximately $5 \mathrm{~h}$, and the opening hours of primary health care centre was same as the working hours of most patients. This causes the respondents who were still actively working tend to have less treatment in primary health care centre due to their inability to visit the primary health care centre.

Adherence in this study was measured based on the total ARMS score. The lowest total ARMS score in this study was 12 and the highest was 33. Based on the data obtained, it showed that the number of days of drug administration for 15 days had the lowest average ARMS score of 13.3 (Table II). The low total ARMS score indicates better adherence (Kripalani et al., 2009). Disease factors such as hypertension make the patient tend to lack spirit with long-term therapy because it does not produce healing. This causes the patient to disobey. Long duration of therapy is also one of the factors of nonadherence (Hussar, 2005).

According to table II, it was seen that patients who received drugs with a long number of days were more adherent than patients who received drugs with a short number of days. The short number of medication days' supply causes the frequency of patients to have to return to the primary health care centre to get the medicine increased. Based on what some respondents said, they feel lazy to return to primary health care centre because they spend a long time to get the service so they prefer not to take the medicine or prefer to buy the medicine in the pharmacy. When the patient does not routinely return to the primary health care centre or choose not to take medication, the patient's blood pressure becomes uncontrolled and it would be difficult to reach the target of the appropriate blood pressure. The presence of such non-adherence may lead to deterioration of the patient's condition, the occurrence of complications, the unability of reaching the goal of the therapy, the increased unwanted reactions of drugs, death, and increased health costs (Hussar, 2005; Osterberg et al., 2005).

In this study, the total cost of the patient during the treatment in the last 1 month was obtained by calculating direct medical costs, direct non-medical costs, and indirect costs. Direct medical costs were calculated by summing up the costs incurred by patients to buy drugs at pharmacies, laboratory examination fees, and medical examination fees outside primary health care centre for the past month. In general, the reason of the respondents to buy antihypertensive drugs in a pharmacy was because in the time required to visit the primary health care centre was longer patients. In addition, the distance to the pharmacy is closer to the respondent's residence than the primary health care centre, and with the cheap price, respondents could get 
all the medication needed. Generally, patients rarely pay for laboratory examination because the cost was borne by the insurance (BPJS).

The direct non-medical costs were calculated from the administrative costs of the primary health care centre, the transportation costs of the patients to the primary health care centre, pharmacies, and doctors outside the primary health care centre for the past month. Transportation costs were calculated based on the cost of public transport issued by the patient or the cost of vehicle fuel per kilometer multiplied by the distance of the patient's house to the primary health care centre, pharmacy, or doctor, including parking fees.

Indirect costs were measured from the cost of reduced productivity at work. In this study, reduced productivity at work was calculated based on the question of how long the respondent complete the affairs at the primary health care centre then multiplied by hourly earnings.

Table III shows the average details of the costs incurred by patients based on patient's real visits to the primary health care centre in one month. It can be seen that the indirect costs or cost of reducing the productivity of respondents when they visit the primary health care centre was the largest cost.

In table III the results of the patient's cost calculations seem to fluctuate. Hence, it was necessary to calculate costs that must be spent if the patient obediently return to the primary health care centre in accordance with the schedule of drug administration (Table IV). This calculation was performed to compare the cost of the patient based on patient's real visit to the primary health care centre and the cost of the patients who obediently visit the primary health care centre in accordance with the schedule of drug administration. Based on the data in table IV, it can be seen that the cost to be paid by patients if they adhere to visit primary health care centre was much higher than the cost based on real visit according to the patient's acknowledgment. The data showed that the fewer days of drug administration, the more often patients have to go back to the primary health care centre, the greater the cost of the patient. This can be a factor that causes patients to rarely return to the primary health care centre in accordance with drug administration schedule. In (Table IV) there was no direct medical cost since the fee has been obtained free of charge from the primary health care centre.

Analysis of the influence of number of days of antihypertensive drug administration on hypertensive patient adherence was done using Spearman correlation test. Based on the results of the analysis in the table $\mathrm{V}$, the value of significant figure was $0.0001(\mathrm{p}<0.05)$. Thus, there was an influence of the medication days' supply on patient adherence. Meanwhile, the influence between the medication days' supply against adherence it seen by looking at the value of correlation coefficient, that was -0.347 , which means the greater the number of days of drug administration, the lower total ARMS score. The low total ARMS score indicated high adherence. This was in accordance with the data obtained in table II, that the fewer medication days' supply, the higher the ARMS score the patient obtained. The higher the ARMS score obtained means the lower the patient's adherence (Kripalani, et al., 2009). Based on the results of analysis using Spearman correlation test (Table V) the value of significan figure for the cost of the patient based on the real visit according to the patient's acknowledgment was 0.755 ( $p>0.05)$ which means there was no influence of the medication days' supply on the cost incurred patient. This was probably due to the majority of patients did not return to the primary health care centre in accordance with the expected frequency of visits. For example, patients who received medication for 4 days, who should return to primary health care centre 7 times a month, based on the patient's acknowledgement, they visited primary health care centre only once a month so there was no difference of patient expense between patients who got drug for 4 days and those who got drug for 30 days because both groups of patients were both visiting the primary health care centre only once a month. However, based on the analysis of the influence of the medication days' supply on the cost that should be spent by the patient if the patient was obedient to return to the primary health care centre in accordance with the number of days of drug administration, the value of significan figure was $0.0001 \quad(p<005)$ with correlation coefficient value -0.247 . 
Table III. The average total cost based on patients' real visit in accordance with the patients' acknowledgment

\begin{tabular}{cccccc}
\hline $\begin{array}{c}\text { Medication } \\
\text { days' supply }\end{array}$ & $\mathbf{n}$ & $\begin{array}{c}\text { Direct medical } \\
\text { cost (IDR) }\end{array}$ & $\begin{array}{c}\text { Direct non medical } \\
\text { cost (IDR) }\end{array}$ & $\begin{array}{c}\text { Indirect cost } \\
\text { (IDR) }\end{array}$ & $\begin{array}{c}\text { Total cost } \\
\text { (IDR) }\end{array}$ \\
\hline 3 days & 7 & $4,421.00$ & $2,875.71$ & $28,372.14$ & $35,669.29 \pm 48,431.47$ \\
4 days & 2 & 0 & 0 & $25,000.00$ & $25,000.00 \pm 35,355.34$ \\
5 days & 66 & $5,125.00$ & $10,324.13$ & $36,890.55$ & $51,469.86 \pm 52,000.73$ \\
6 days & 31 & $4,011.00$ & $4,656.03$ & $34,615.68$ & $43,282.68 \pm 58,738.89$ \\
7 days & 42 & $1,226.00$ & $8,677.53$ & $34,348.24$ & $43,284.43 \pm 42,227.29$ \\
8 days & 4 & 0 & $20,766.75$ & $10,250.00$ & $31,016.75 \pm 31,460.62$ \\
10 days & 195 & $2,847.00$ & $12,719.79$ & $40,484.89$ & $54,386.84 \pm 47,504.92$ \\
14 days & 16 & 62.00 & $11,049.79$ & $49,969.06$ & $59,699.44 \pm 81,122.21$ \\
15 days & 4 & 0 & $8,185.00$ & $32,224.75$ & $38,363.50 \pm 40,095.78$ \\
30 days & 39 & $1,795.00$ & $7,716.69$ & $17,146.79$ & $27,473.68 \pm 28,598.27$ \\
\hline
\end{tabular}

Table IV. The average cost that should be spent if patients regularly visited the primary health care centre on schedule

\begin{tabular}{ccccr}
\hline $\begin{array}{c}\text { Medication } \\
\text { days' supply }\end{array}$ & $\mathbf{n}$ & $\begin{array}{c}\text { Direct non medical } \\
\text { cost (IDR) }\end{array}$ & $\begin{array}{c}\text { Indirect cost } \\
\text { (IDR) }\end{array}$ & \multicolumn{1}{c}{$\begin{array}{c}\text { Total cost } \\
\text { (IDR) }\end{array}$} \\
\hline 3 days & 7 & $8,899.14$ & $187,961.90$ & $196,861.04 \pm 144,482.8$ \\
4 days & 2 & 0 & $92,500.00$ & $92,500.00 \pm 45,961.94$ \\
5 days & 66 & $20,500.51$ & $122,691.60$ & $143,192.11 \pm 127,520.2$ \\
6 days & 31 & $11,618.62$ & $68,453.72$ & $80,072.34 \pm 64,797.15$ \\
7 days & 42 & $10,711.12$ & $84,720.00$ & $95,431.12 \pm 58,809.41$ \\
8 days & 4 & $57,286.33$ & $34,750.00$ & $92,036.33 \pm 62,678.14$ \\
10 days & 195 & $13,085.67$ & $70,106.82$ & $83,192.49 \pm 78,280.01$ \\
14 days & 16 & $9,953.00$ & $59,984.44$ & $69,937.44 \pm 80,855.46$ \\
15 days & 4 & $6,138.25$ & $32,224.75$ & $38,363.01 \pm 40,096.34$ \\
30 days & 39 & $8,515.64$ & $29,975.74$ & $38,491.38 \pm 53,648.62$ \\
\hline
\end{tabular}

Table V. Spearman correlation test result of the influence of medication days' supply on adherence and cost in hypertensive patients $(\mathrm{n}=406)$

\begin{tabular}{lcc}
\hline & Correlation coefficient (r) & p value \\
\hline $\begin{array}{l}\text { Total ARMS score } \\
\begin{array}{l}\text { Cost based on patients' real visit in accordance with } \\
\text { the patients' acknowledgment }\end{array}\end{array}$ & -0.347 & 0.0001 \\
$\begin{array}{l}\text { Cost that should be spent if patients regularly visited } \\
\text { the primary health care centre on schedule }\end{array}$ & 0.015 & 0.755 \\
\hline
\end{tabular}

It means there was influence of medication days' supply on cost incurred by patients. The greater the medication days' supply, the lower the cost incurred by patients.

\section{Limitation of the study}

In this study cost data was obtained based on the patient's acknowledgement of the cost associated with hypertension during the last month, so it was probable what the patient recall was different from the actual cost. We suggest for further studies using patient diary method to give better precision of cost data.

Different number of medication days' supply consistently indicates the effect on adherence. In this research, the consistency test was done by comparing the result of correlation 
test between medication days' supply and cost according to the patient acknowledgement with cost simulation if the patient return to primary health care centre according to schedule. The results of this analysis indicate that the conclusion of correlation test results may change due to the frequency of patient visits greatly affect the total cost incurred by the patient.

\section{CONCLUSION}

Medication days' supply influences adherence and costs incurred by hypertensive patients who seek treatment at primary health care centre. Patients who were given the drug for 30 days showed better adherence with a lower cost burden.

\section{ACKNOWLEDGEMENT}

This research was supported by Primary Health Care Centres in Surabaya.

\section{REFERENCES}

Aldila, F. 2015. Kepatuhan pasien penggunaan obat antibipertensi di Puskesmas Kedurus Surabaya Selatan (skripsi). Surabaya: Fakultas Farmasi Universitas Airlangga.

Ananda, MR. 2015 Kepatuban penggunaan obat antibipertensi di Puskesmas Pacarkeling (skripsi). Surabaya: Fakultas Farmasi Universitas Airlangga.

BPJS Kesehatan 2013 'Seputar BPJS Kesehatan', p. 46.

Chobanian, AV., Bakris, G. and Black, H. 2003. 'The seventh report of the joint national committee on prevention, detection, evaluation, and treatment of high blood pressure (JNC7)', J byp, 42(6), pp. 12061252.

Depkes, R. (2006) harmacentical care untuk pasien penyakit hipertensi. Jakarta: Departemen Kesehatan Republik Indonesia.

Dinkes Surabaya 2015 Profil Kesehatan Tahun 2015. Surabaya: Pemerintah Kota Surabaya, Dinas Kesehatan.

Hussain, MA. et al. 2016 'Prevalence, awareness, treatment and control of hypertension in Indonesian adults aged $\geq 40$ years: Findings from the Indonesia Family Life Survey (IFLS)', PLOS ONE, 11(8), pp. 116. doi: 10.1371 /journal.pone. 0160922.

Hussar, DA. 2005 'Patient Compliance', in
Gennaro, AR. (ed.) Remington: The Science and Practice of Pharmacy. 21st edn. Philadelphia: Lippincott Williams \& Wilkins, pp. 1782-1792.

Kaplan, N. 2002. Kaplan's Clinical Hypertension. 8th edn. Philadelphia: Lippincott Williams and Wilkins.

Kemenkes RI 2013. Riset Kesehatan Dasar. Jakarta: Badan Penelitian dan Pengembangan Kesehatan Kementrian Kesehatan RI.

Khanal, MK. et al. 2017. 'Prevalence, associated factors, awareness, treatment , and control of hypertension: Findings from a cross sectional study conducted as a part of a community based intervention trial in Surkhet, Midwestern region of Nepal', PLoS ONE, 12(10), pp. 1-20. doi: 10.5061/dryad.1rb14.

Kripalani, S. et al. 2009. 'Development and evaluation of the adherence to refills and medications scale (ARMS) among lowliteracy patients with chronic disease.', $V$ alue in health, 12(1), pp. 118-123.

Osterberg, L., Blaschke, T. and Koop, - C Everett 2005 'Adherence to Medication', $N$ Engl J Med, 353, pp. 487-497. doi: 10.1056/NEJMra050100.

Rajpura, J. Nayak, R. 2014. 'Medication adherence in a sample of elderly suffering from hypertension: evaluating the influence of illness perceptions, treatment beliefs, and illness burden.', JMCP, 20(1), pp. 58-65. doi: 10.18553/jmcp.2014.20.1.58.

Riska, NE. 2015. Kepatuhan pasien pada penggunaan obat antibipertensi dengan menggunakan metode MMAS-08 dan metode pill count di Puskesmas Tambakrejo Surabaya Pusat (skripsi). Surabaya: Fakultas Farmasi Universitas Airlangga.

Saseen,JJ.MacLaughlin,EJ.2008 'Hypertension', in Dipiro, Pharmacotherapy: A Pathophysiologic Approach. 7th edn. New York: The Mc Graw-Hill Companies, Inc.

Sokol, MC. et al. 2005 'Impact of medication adherence on hospitalization risk and healthcare cost.', Medical Care, 43(6), pp. 521-530. doi: 10.1097/01.mlr.0000163641.86870.af. 
Taitel, M. et al. 2012. 'Medication days' supply, adherence, wastage, and cost among chronic patients in Medicaid.', Medicare \& medicaid research review, 2(3), pp. 1-13. doi: 10.5600/mmrr.002.03.a04.

Voorham, J. et al. 2011. 'Medication Adherence Affects Treatment Modifications in Patients With Type 2 Diabetes', Clinical Therapeutics, 33(1), pp. 121-134.

WHO 2003). 'Adherence to Long Term
Therapies: Evidence for Action, World Health Organization'. Switzerland: World Health Organization.

WHO 2011. 'Hypertension Fact Sheet', Hypertension Fact Sheet. WHO Regional Office for South-East Asia. Available at: http://www.searo.who.int/entity/nonco mmunicable_disease/media/non_comm unicable_disease_hypertension_fs.pdf. 